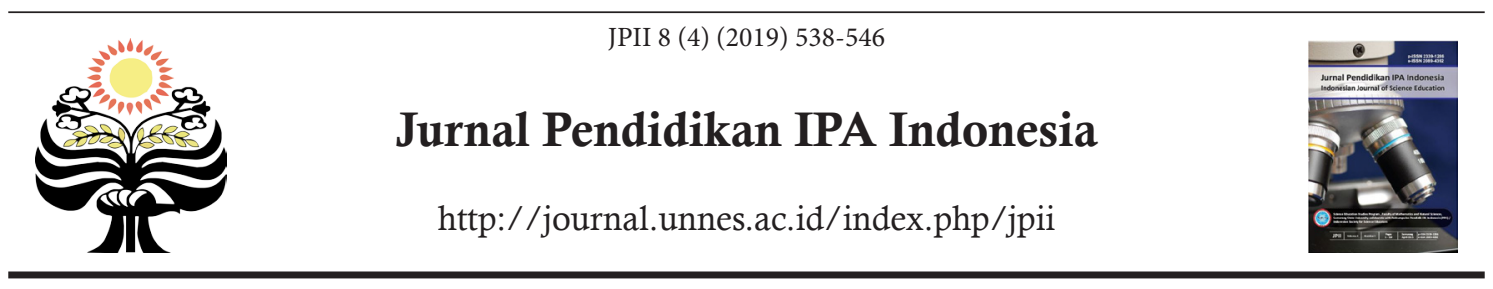

\title{
ITEM ANALYSIS OF CRITICAL THINKING SKILLS INSTRUMENT TO MEASURE EFFECTIVENESS OF SCIENTIFIC GROUP INQUIRY LEARNING (SGIL) MODEL
}

\author{
M. D. Wijayanti*1, S. B. Rahardjo ${ }^{2}$, S. Saputro ${ }^{3}$, S. Mulyani ${ }^{4}$ \\ ${ }^{1}$ Doctoral Program in Science Education, Faculty of Teacher Training and Education, \\ Sebelas Maret University Surakarta, Indonesia \\ ${ }^{2,3,4}$ Departement of Science Education, Faculty of Teacher Training and Education, \\ Sebelas Maret University, Indonesia
}

DOI: 10.15294/jpii.v8i4.20794

Accepted: July $16^{\text {th }}, 2019$. Approved: December 27 $7^{\text {th }}, 2019$. Published: December $31^{\text {st }}, 2019$

\begin{abstract}
The purpose of this study is to analyze the problem set items to get information and feedback on critical thinking skills tests. This research develops a SGIL model that can improve students' critical thinking learning. This study uses a research and development design to develop the SGIL model. The SGIL model is proven to be able to improve the critical understanding of PGSD students. The syntax of SGIL consists of 6 steps, namely: (1) discussion of problems and topic selection; (2) research planning; (3) implementation; (4) data integration; (5) analysis and synthesis; and (6) conclusions and communication. The participants were 114 Elementary Teacher Education Program (PGSD) students who were selected by using a random sampling technique. This research was conducted in 3 sample universities. The data of SGIL model effectiveness was measured by using instrument of critical thinking skills. This instrument has been analyzed for its validity, reliability, level of difficulty, and discrimination item. Tests to obtain data were carried out for 90 minutes. The instrument was calculated by using analysis of Quest and Lisrel.
\end{abstract}

(C) 2019 Science Education Study Program FMIPA UNNES Semarang

Keywords: critical thinking skills, PGSD, SGIL

\section{INTRODUCTION}

The challenge of the $21^{\text {st }}$ century in the world of education is to build a competitive generation in facing the era of increasingly advanced globalization. The era of globalization requires human resources who have intelligence, knowledge, and high-level thinking skills, including teachers who have an important role in producing highly competitive students. The success of learning objectives is determined by the role of the teacher in the learning process (Bashir \& Bala,

*Correspondence Address

E-mail: murwanidewi@student.uns.ac.id
2018; Mukeredzi, 2013). The teacher has a role in managing the class when they collaborate with other teachers. Classroom management can run well, if supported by teachers who are competent in teaching. Good teaching is one that can teach material through direct and contextual experience (Pukdeewut et al., 2013). Today, technological advances influence the world of education, both ways of teaching and learning processes (Kocakaya \& Gnen, 2013) specifically parents' education, income and students' prior learning affect the children's academic achievement and affective characteristics (attitude and self-efficacy. In the learning process, the teacher must master many 
things. They need to be equipped with thinking skills that make it easier to find factual, relevant, and trustworthy information. Thinking skills will support science communication, innovation, and critical thinking skill (Alfin \& Fuad, 2019; Pandiangan et al., 2017; Jatmiko et al., 2018; Sunarti \& Prahani, 2018). In fact, there are many evidences that many student in some universities have less skill in critical thinking (Zarifsanaiey et al., 2016). Abramova et al. (2013) found a fact that many lectures dominate the learning, therefore, student centered learning is limited. Abundant PGSD materials cause the lecturer to focus in solving rather than allowing students to think. Student receive more materials and less practice in thinking skill (Azmi et al., 2013; Vlachos et al., 2013).

According to Mapeala \& Siew, (2015)sequencing, and identifying cause and effect. The initial TSCT consisted of 55 multiple choice test items, each of which required participants to select a correct response and a correct choice of critical thinking used for their response. Data were obtained from a purposive sampling of 30 fifth graders in a pilot study carried out in a primary school in Sabah, Malaysia. Students underwent the sessions of teaching and learning activities for 9 weeks using the Thinking Maps-aided ProblemBased Learning Module before they answered the TSCT test. Analyses were conducted to check on difficulty index ( $p$, a the characteristics of critical individuals are bringing new meaning or purpose in a task, finding new usages, solving problems, or providing added value or beauty. They also express real personal characteristics such as imaginative, have broad interests, be independent in thinking, are full of energy, confident, dare to take risks, and are brave in the establishment and belief. The indicators of critical thinking skills in this study used the formulation of Ennis, (1991). Critical thinking skills include: (1) providing simple explanations; (2) building basic skills; (3) concluding; (4) providing further explanation; and (5) arranging strategies and tactics.

The PGSD program has a role in preparing prospective elementary school teachers who have critical thinking skills. PGSD lecturers have a task in preparing elementary teacher candidates who have critical thinking skills (Sinaga \& Feranie, 2017; DemIrhan, 2014). A big challenge for lecturers is to stimulate students' critical thinking skills. Based on the obtained data, the consistency of critical thinking skills of PGSD UNS Surakarta students is still low. The consistency in critical thinking shows a level of low consistency at $54.85 \%$. The low consistency of critical thinking is due to the problem solving of science based only on knowledge of theories and concepts (Wijayanti et al., 2016).

Critical thinking can be applied in various fields of science, according to the chosen field.
Science is very diverse, one of them learns about the basic concepts of science. Learning the basic concepts of natural science, especially energy material task, is integrated from the branches of physics, chemistry, and biology (Wijayanti, et al, 2018). Critical thinking skills are related to students' cognitive abilities in active learning. Through the learning process, students learn to select information received and determine truth in creating new ideas (Paul \& Elder, 2014; FitzPatrick \& Schulz, 2015). Students can also analyze, evaluate, summarize, and solve problems together when the learning process is carried out (Dwyer, Kozmian-Ledward, \& Stockin, 2014) vessel collisions with small cetaceans were presumed rare, mainly as a consequence of limited reporting. Observations on dolphin wound healing from propeller strike injuries also remain scarce. We present an extreme case of a bottlenose dolphin (Tursiops truncatus.

A learning model cannot be implemented for all courses. Each course with certain material has certain characteristics. Creative lecturers can manage their class well (Pukdeewut et al., 2013). Therefore it needs a right learning model that suits students' needs. Submission of an appropriate learning model can improve students' skills in thinking independently and critically (Hudha et al., 2017). Previous research shows that learning that is often used in PGSD is inquiry (Wijayanti et al., 2018). Learning models that are often used to improve critical thinking skills are based on concept discovery. Learning models still require further development to improve critical thinking skills. Some studies show that the application of inquiry model has an effect on improving students' science concepts compared to traditional models (Nasution, 2015). The reality in the field shows that inquiry has weaknesses, for example it requires a long time so it is difficult to analyze the data. Studied (Ratnasari et al., 2018; Yusrizal, 2016; Susongko, 2016).

Measurement of the success of learning can be conducted by testing. The measured test is a test of critical thinking skills. Test items need to be analyzed so that students get proper grades and quality. Tests are good if they meet characteristics such as validity, reliability, difference in power and difficulty levels. So far, there have been no instruments used to measure critical thinking skills in the Scientific Group Inquiry Learning (SGIL) model. Based on those problems, the researchers are interested in examining the item analysis of critical thinking skills instruments to measure the effectiveness of scientific group inquiry learning (SGIL). The purpose of this study is to acknowledge the quality of the critical thinking 
skills test in terms of validity, reliability, questionability, and level of difficulty in PGSD students. This research offers a solution to measure critical skills with SGIL basis for PGSD students, especially on energy material topics.

\section{METHODS}

This research is a quantitative descriptive type. The data obtained were analyzed statistically and then synthesized to get new conclusions (Sugiyono, 2015: 14).

The subjects of SGIL were PGSD students from 3 sample universities, which are UNS, UMS, and UNIPMA. The purpose of this study is to produce a SGIL model that is feasible and effective in increasing critical thinking skills. This study applied the design of Research \& Development (R\&D). Data collection was performed with a critical thinking skills test consisting of 20 items, 114 answer sheets, and answer keys. The data analysis technique was conducted by analyzing the validity, reliability, level of difficulty, and different power of questions with the Quest program. The quest program is useful to identify whether the model is appropriate or identify the problem difficulty index. The model fits if the MNSQ is in the range of $0.77-1.30$. The instrument is reliable if it fulfills an index equal to or greater than 0.70 . The instrument difficulty index is good if it is between -2 to +2 .

\section{RESULTS AND DISCUSSION}

The results of the large-scale field operational tests of the SGIL model were over the results of critical thinking skills test. The results of the questionnaire are presented in diagram form as in Figure 1.

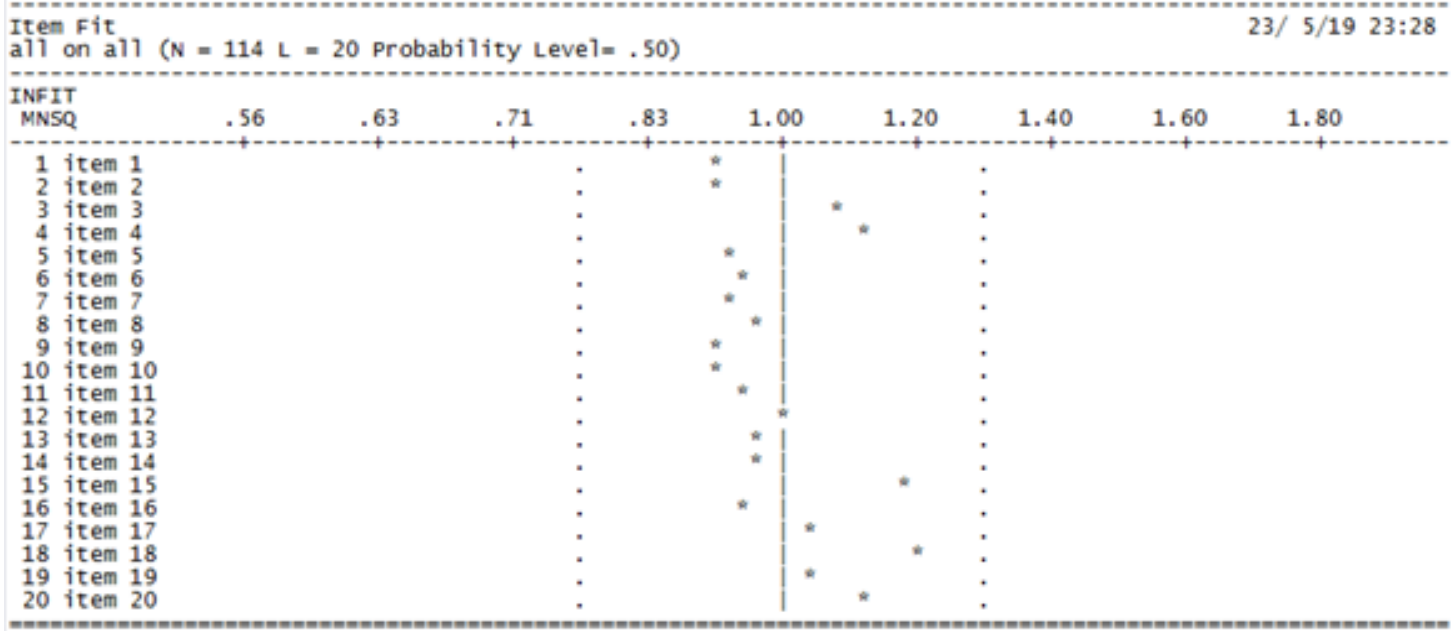

Figure 1. Critical Thinking Skill Test Results on the Implementation of the SGIL Model

Figure 1 shows the average total value of the three aspects, the majority of which are in the good category, because it is between -2 to +2 . The results of the test show that the critical thinking test fits (valid) for SGIL models used to learn the basic concepts of Natural Sciences in energy material.

The results of reliability with Quest program on the critical thinking skills test can be seen in Figure 2.

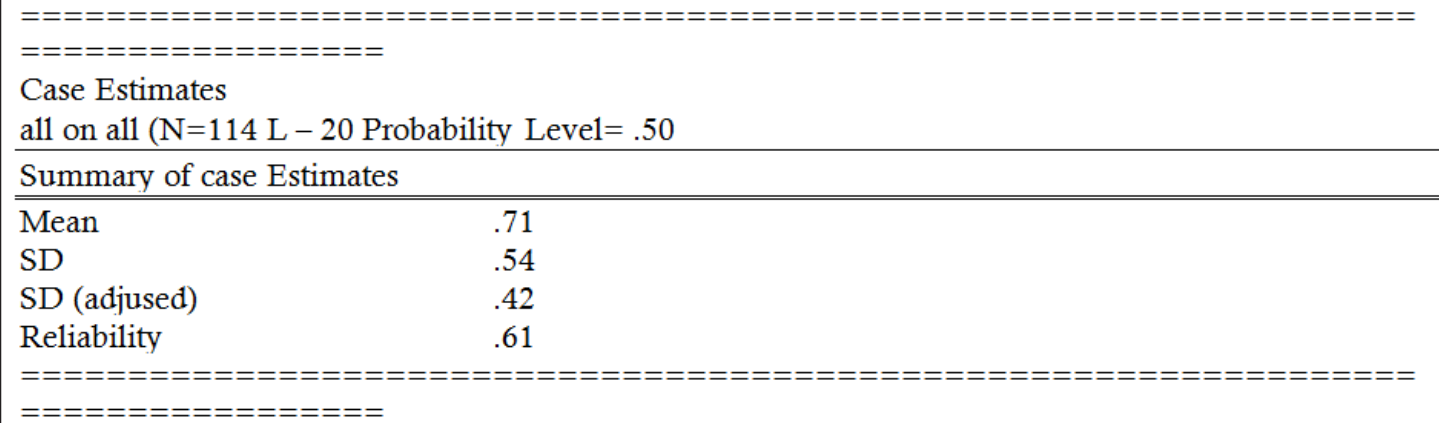

Figure 2. Results of Reliability with Quest Program 
The criteria of Reliability coefficient consist of 5 categories. The coefficient $0.90<\mathrm{r}<1.00$ shows very high reliability level. Coefficient of $0.70<\mathrm{r}<0.89$ shows high reliability. Coefficient of $0.40<\mathrm{r}<0.69$, shows medium reliability. Coefficient of $0.20<\mathrm{r}<0.39$ shows low reliability value, and coefficient of $0.00<\mathrm{r}<0.19$ shows very low reliability. The percentage results of the analysis of the difficulty of the questions with Quest are shown in Table 1.

Table 1. Results of the Analysis of the Difficulty of the Questions with Quest

\begin{tabular}{ccc}
\hline No & Criteria & Percentage (\%) \\
\hline 1 & Very easy & 0,0 \\
2 & Easy & 5,0 \\
3 & Enough & 85,0 \\
4 & Good & 10,0 \\
5 & Very good & 0,0 \\
\hline
\end{tabular}

The reliability of energy material critical thinking skills tests in PGSD students amounted to a coefficient value of 0.61 . Based on the criteria of reliability value, it can be categorized as medium. The magnitude of the difficulty index for a good test item is in the range of 0.30 to 0.70 (Mapeala \& Siew, 2015)sequencing, and identifying cause and effect. The initial TSCT consisted of 55 multiple choice test items, each of which required participants to select a correct response and a correct choice of critical thinking used for their response. Data were obtained from a purposive sampling of 30 fifth graders in a pilot study carried out in a primary school in Sabah, Malaysia. Students underwent the sessions of teaching and learning activities for 9 weeks using the Thinking Maps-aided Problem-Based Learning Module before they answered the TSCT test. Analyses were conducted to check on difficulty index (p. Afterward, the results of the item analysis were used to measure the effectiveness of the SGIL in improving critical thinking skills.

\section{Recapitulation of SGIL effectiveness results at Sebelas Maret University (UNS), Muhammadiah Surakarta University (UMS) and PGRI Madiun University (UNIPMA)}

The achievement of students' critical thinking skills of students is measured by using a critical thinking skills test for energy material. Data analysis results in critical thinking skills test scores before and after treatment (pretest and posttest). The average score obtained by the standard gain (N-gain) increases students' critical thinking skills in certain categories (Pandiangan et al., 2017). The results of the analysis of critical thinking skills scores of UNS students are presented in Table 2.

Table 2. Results of Critical Thinking Skills Tests

\begin{tabular}{lcccccc}
\hline & $\begin{array}{c}\text { Syntax } \\
\text { SGIL }\end{array}$ & N & Mean & $\begin{array}{c}\text { Std. De- } \\
\text { viation }\end{array}$ & $\begin{array}{c}\text { Std. } \\
\text { Error } \\
\text { Mean }\end{array}$ \\
\hline $\begin{array}{c}\text { Critical } \\
\text { Thinking } \\
\text { Skill }\end{array}$ & Before & 218 & 3.0674 & .27309 & .01850 \\
& After & 200 & 2.8033 & .25682 & .01816 \\
\hline
\end{tabular}

Critical thinking skills test results show an increase in the value of Gain (N-Gain) in the three places where the SGIL model were applied. UNS Gain Score shows three sub-materials that are in the high category. N-Gain scores for UMS and UNIPMA show two sub-materials that are in the high category. The results of the lisrel t-value at the pretest are shown in Figure 3.

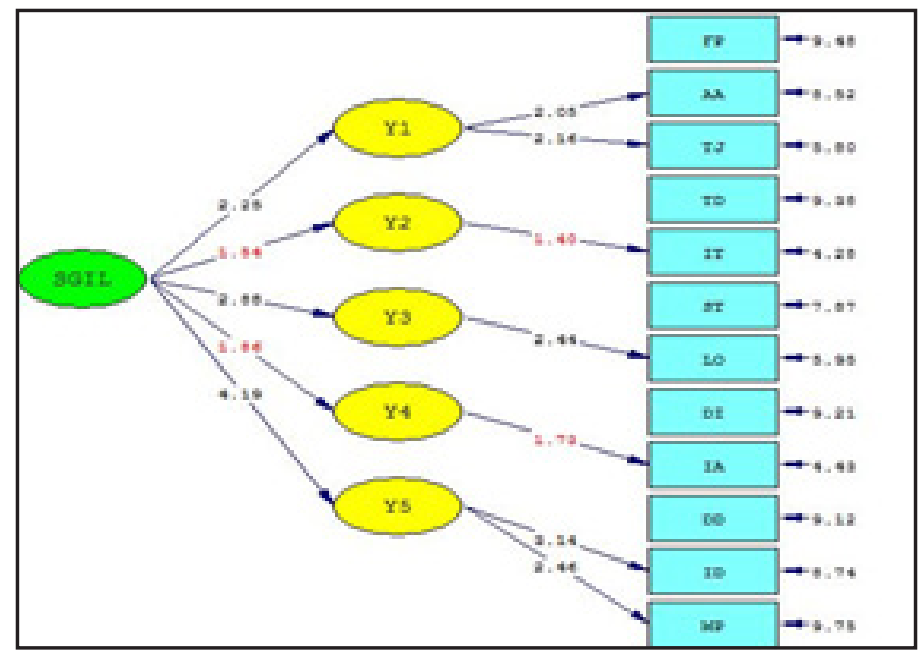

Figure 3. Pretest Results of Researcher's Processed Lisrel t-value 
Model fit criteria in the pretest problem can be seen in the fit index value, compared to the

Table 3. Result of Fit Index standard value $<0.05$. The fit index results can be observed from Table 3.

\begin{tabular}{clccc}
\hline No & Fit Index & Value & Standard Value & Explanation \\
\hline 1 & Chi Square $\mathrm{p}$ & $66.54(\mathrm{df}=49 \cdot \mathrm{p}=0.0452)$ & $<0.05$ & Poor Fit \\
2 & RMSEA & 0.042 & $<0.08$ & Fit \\
3 & NFI & 0.66 & $>0.90$ & Poor Fit \\
4 & NNFI & 0.81 & $>0.90$ & Poor Fit \\
5 & CFI & 0.92 & $>0.90$ & Fit \\
6 & IFI & 0.91 & $>0.90$ & Fit \\
7 & GFI & 0.95 & $>0.90$ & Fit \\
8 & AGFI & 0.92 & $>0.90$ & Fit \\
\hline
\end{tabular}

Table 3 shows that about $75 \%$ of indexes are categorized as fit. These results indicate that the theoretical model of the SGIL variable fits with empirical data. Based on the results of the analysis of the construct validity and the construct reliability, all aspects and items that make up the SGIL are declared valid and reliable so that all aspects and indicators are able to reflect and shape the SGIL.

The effectiveness of critical thinking skills is shown by an increase in posttest results. The results of the processed t-value researchers at posttest can be seen in Figure 4.

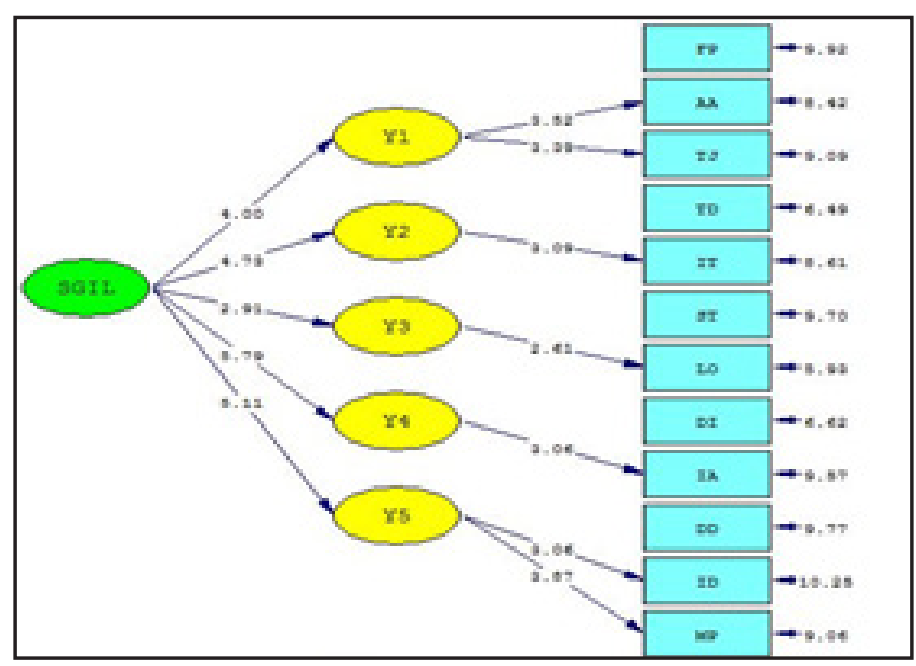

Figure 4. Posttest Results of Researcher's Processed Lisrel T-value

Figure 4 shows that from the aspect of cri- on of fit criteria analysis. The fit criteria analysis tical thinking skills, it is stated to fit with 12 in- shows that $87.5 \%$ were declared fit. The results dicators of critical thinking skills. The processed of the comparison of the fit index between values results in Figure 4 are supported by the calculati- and standard values can be observed in Table 4.

Table 4. Comparison of Fit Index between Value and Standard Value

\begin{tabular}{clccc}
\hline No & \multicolumn{1}{c}{ Fit Index } & Value & Standard Value & Description \\
\hline 1 & Chi Square $\mathrm{p}$ & $88.03(\mathrm{df}=49 \cdot \mathrm{p}=0.003)$ & $<0.05$ & Poor Fit \\
2 & RMSEA & 0.061 & $<0.08$ & Fit \\
3 & NFI & 0.97 & $>0.90$ & Fit \\
4 & NNFI & 0.93 & $>0.90$ & Fit \\
5 & CFI & 0.93 & $>0.90$ & Fit \\
6 & IFI & 0.92 & $>0.90$ & Fit \\
7 & GFI & 0.94 & $>0.90$ & Fit \\
8 & AGFI & 0.91 & $>0.90$ & Fit \\
\hline
\end{tabular}


The effectiveness of the SGIL Model in improving critical thinking skills is demonstrated through Lisrel.

\section{Pretest Results of Implementing the SGIL Model on a Large Scale}

The first level of analysis was started from the latent constructs of aspects (Y1, Y2, Y3, Y4, and Y5) to its indicators. The results show that all factor loading values $>0.5$ and all t-values required to test the Significance of factor loading values are greater than 1.96 , except for the indicators FP, TD, ST, DI, and DD. This means that the 12 items that measure the SGIL are valid and significant for SGIL.

The second level of analysis was resulted from the latent construct (SGIL) to its aspect constructs (Y1, Y2, Y3, Y4, and Y5). The test results show that the factor loading values are all $>0.5$ and all the calculated t-values needed to test the significance of the factor loading values are greater than 1.96. This means that of the 5 aspects that measure SGIL are valid and significant aspects of SGIL.

These results indicate that the theoretical model of the SGIL variable fits with empirical data (Garrison et al., 2001; Leijen et al., 2014; Tiruneh et al., 2016). Based on the results of the analysis of the construct validity and the construct reliability, all aspects and items that make up the SGIL are declared valid and reliable so that all aspects and indicators are able to reflect and shape the SGIL.

\section{Posttest Results of the Implementation of the SGIL Model on a Broad Scale}

The first level of analysis was conducted from the latent constructs of aspects (Y1, Y2, Y3, $\mathrm{Y} 4$, and $\mathrm{Y}$ ) to their indicators. The results of the analysis show that all factor loading values $>0.5$ and all $\mathrm{t}$-values required to test the significance of factor loading values are greater than 1.96, except for the indicators FP, TD, ST, DI, and DD. This means that 12 items that measure the SGIL are all valid and significant for SGIL.

The second level of analysis was carried out from the latent construct (SGIL) to its aspect constructs (Y1, Y2, Y3, Y4, and Y5). The test results above show that the factor loading values are all $>0.5$ and all the calculated t-values needed to test the significance of the factor loading values are greater than 1.96. This means that of the 5 aspects that measure SGIL are valid and significant aspects of SGIL.
Based on the analysis, 7 out of 8 indexes found that the model fit. These results indicate that the theoretical model of the SGIL variable fits with empirical data. Based on the results of the analysis of the construct validity and the construct reliability, all aspects and items that make up the SGIL are declared valid and reliable so that all aspects and indicators are able to reflect and shape the SGIL.

The development of the syntax of the Scientific Group Inquiry Learning (SGIL) model consists of 6 stages: (1) problem identification and topic selection; (2) experimental planning; (3) implementation; (4) data collection; (5) analysis and synthesis; and (6) conclusions and communication.

In stage 1 (problem identification and topic selection), problem identification can be developed by topic selection. Energy material in the Energy course is divided into 8 topics. Time limitations which become the weaknesses of inquiry can be minimized by forming groups by sharing energy topics. Each group has responsibility to identify problems in each topic that they will solve together.

In stage 2 (experimental planning), students who are already divided into work groups plan problem solving through an experimental plan. At this stage students are given opportunities to establish social communication and share ideas in making experiments.

In phase 3 (implementation), students conduct experimental planning that has been designed in an experiment in the group that has been formed. From this experiment, social interaction can occur. Every student has the same role. They can exchange opinions and provide input while working on assignments (Gunes et al., 2015). Every data generated is collected and recorded as one part of the learning phase.

In stage 4 (data collection), data generated in the implementation activities are grouped according to their respective topics. After the data collection is done, the process continues to stage 5 (analysis and synthesis). Existing data are analyzed and synthesized with a group of friends. At the analysis stage each student is free to argue.

Data are analyzed whether it is in accordance with the theory or not. They seek answers through group discussions. The results of the discussion are synthesized and written in the form of a report. At this stage, it can be seen that students are increasingly challenged to raise their arguments (Stapleton \& Amy, 2015). Students are encouraged to improve their critical thinking skills. Based on oral interviews, students do this becau- 
se they feel the experiment is a self-planning.

In stage 6 (conclusions and communication), each group draws conclusions of their work then communicates in the presentation. UNS students on average conduct presentations with teaching aids and demonstrations. UMS students use power points and LCDs. UNIPMA students conduct a live presentation, two groups are formed to show demonstration to support their conclusions. As an individual assignment, each student makes a report based on the experiments that have been conducted (Özarslan et al., 2013). The series of stages of learning in the three sample universities supports the discovery and extensive social interaction (Gyllenpalm, 2018).

Learning from the results of the study shows that what has been done is in accordance with the theory of constructivism which is the basis of SGIL. Knowledge can be developed by students so that they can create science learning strategies effectively (Nadelson et al., 2011; Torre et al., 2017). Students will be more active in developing accepted concepts, so they are able to develop critical thinking skills on the material being studied (Demirhan et al., 2014; Semwal \& Bhatt, 2013)

\section{CONCLUSION}

The SGIL model is a cooperative learning based problem solving which is designed to improve critical thinking skills for prospective elementary school teachers. The five-phase SGIL model includes: (1) problem identification and topic selection; (2) experimental planning; (3) implementation; (4) data collection; (5) analysis and synthesis; and (6) conclusions and communication. The results of the study show the SGIL model with valid content average - average (3.83), construct validity (3.96), with the validity of each aspect statistically in $(\mathrm{r} \alpha=1.00)$ and reliability in $(\alpha=1.00)$. It can be concluded that the SGIL model meets the requirements (valid in content and construction, and can be declared feasible and appropriate by experts). The implication of this research is that the SGIL Model is a model characterized by cooperative findings. The SGIL model can improve the critical thinking skills of PGSD students, where lecturers act as a facilitator with a few modifications during the learning process. Contextual learning is done with learning resources, varied media, and widely formed social systems.

\section{ACKNOWLEDGEMENTS}

Acknowledgment from the authors is addressed to Sebelas Maret University of Surakarta, Muhhamadiyah University of Surakarta and PGRI Madiun University, which have implemented the SGIL model.

\section{REFERENCES}

Abramova, I., Ananyina, A., \& Shishmolina, E. (2013). Challenges in Teaching Russian Students to Speak English. American Journal of Educational Research, 1(3), 99-103.

Alfin, J., \& Fuad, A. (2019). Development of Group Science Learning (GSL) Model to Improve the Skills of Collaborative Problem Solving, Science Process, and SelfConfidence of Primary Schools Teacher Candidates. International Journal of Instruction, 12(1), 147-164.

Azmi, M. N. L., Samsuddin, N. W., \& Rahman, M. A. (2013). Fairclough's Concepts of Language Policy and Language Planning: A Comparative Study between Malaysia and Cambodia. American Journal of Educational Research, 1(9), 375-379.

Bashir, H., \& Bala, R. (2018). Development and Validation of Academic Dishonesty Scale (ADS): Presenting a Multidimensional scale. International Journal of Instruction, 11(2), 57-74.

Demirhan, E., Önder, İ., \& Beşoluk, Ş. (2014). Brain Based Biology Teaching: Effects on Cognitive and Affective Features and Opinions of Science Teacher Trainees. Journal of Turkish Science Education (TUSED), 11(3), 65-78.

Dwyer, S., Kozmian-Ledward, L., \& Stockin, K. (2014). Short-Term Survival of Severe Propeller Strike Injuries and Observations on Wound Progression in a Bottlenose Dolphin. New Zealand Journal of Marine and Freshwater Research, 48(2), 294-302.

Ennis, R. (1991). Critical Thinking: A Streamlined Conception. Teaching Philosophy, 14(1), 5-24.

FitzPatrick, B., \& Schulz, H. (2015). Do Curriculum Outcomes and Assessment Activities in Science Encourage Higher Order Thinking? Canadian Journal of Science, Mathematics and Technology Education, 15(2), 136-154.

Garrison, D. R., Anderson, T., \& Archer, W. 
(2001). Critical Thinking, Cognitive Presence, and Computer Conferencing in Distance Education. American Journal of Distance Education, 15(1), 7-23.

Gunes, P., Katircioglu, H., \& Yilmaz, M. (2015). The Effect of Performance Based Evaulation on Preservice Biology Teachers' Achievement ond Laboratory Report Writing Skills. Journal of Turkish Science Education, 12(1), 71-83.

Gyllenpalm, J. (2018). Inquiry and Flow in Science Education. Cultural Studies of Science Education, 13(2), 429-435.

Hudha, A. M., Amin, M., \& Bambang, S. (2017). Study of Instructional Models And Syntax as an Effort for Developing 'OIDDE' Instructional Model. Jurnal Pendidikan Biologi Indonesia, 2(2), 109-124.

Jatmiko, B., Prahani, B. K., Supardi, Z. A., Wicaksono, I., Erlina, N., Pandiangan, P., \& Althaf, R. (2018). The Comparison of Oripa Teaching Model and Problem Based Learning Model Effectiveness to Improve Critical Thinking Skills of Pre-Service Physics Teachers. Journal of Baltic Science Education, 17(2).

Kocakaya, S., \& Gnen, S. (2013). Effects of Demographic and Affective Characteristics on Physics Achievement: A Structural Equation Modeling Approach. Journal of Turkish Science Education, 10(1), 28-43.

Leijen, Ä., Allas, R., Toom, A., Husu, J., \& Mena, J.-J. (2014). Guided Reflection for Supporting the Development of Student Teachers' Practical Knowledge. Procedia Social and Behavioral Sciences, 112(Iceepsy 2013), 314-322.

Mapeala, R., \& Siew, N. M. (2015). The Development and Validation of a Test of Science Critical Thinking for Fifth Graders. SpringerPlus, 4(1), 741.

Mukeredzi, T. G. (2013). The Journey to Becoming Teaching Professionals in Rural South Africa and Zimbabwe. Australian Journal of Teacher Education, 38(10), 83-104.

Nadelson, L., Williams, S., \& Turner, H. (2011). Impact of inquiry-Based Science Interventions on Middle School Students' Cognitive, Behavioral, and Affective Outcomes. Campbell Systematic Reviews, 1-9. Retrieved from http://campbellcollaboration.org/ $\underline{\mathrm{lib} / \mathrm{project} / 192 /}$

Nasution, F. H. (2015). The Effect of Scientific Inquiry Learning Model Based on Conceptual Change on Physics Cognitive Competence and Science Process Skill (SPS) of Students at Se- nior High School (Doctoral dissertation, UNIMED).

Özarslan, M., Çetin, G., \& Saritaş, T. (2013). Biyoloji, fizik ve Kimya Öğretmen Adaylarinin bilgi ve Iletişim Teknolojilerine Yönelik Tutumlari. Journal of Turkish Science Education, 10(2), 85-100.

Pandiangan, P., Sanjaya, I. G. M., \& Jatmiko, B. (2017). The Validity and Effectiveness of Physics Independent Learning Model to Improve Physics Problem Solving and Selfdirected Learning Skills of Students in Open and Distance Education Systems. Journal of Baltic Science Education, 16(5), 651-665.

Paul, R., \& Elder, L. (2014). The "AHA!" Approach or Critical Thinking and Understanding Concepts. Performance Instruction, 34(6), 14-17.

Pukdeewut, S., Chantarasombat, C., \& Satapornwong, P. (2013). Creative Thinking Development Program for Learning Activity Management of Secondary School Teachers. International Education Studies, 6(12), 82-94.

Ratnasari, D., Sukarmin, S., Suparmi, S., \& Harjunowibowo, D. (2018). Analysis of Science Process Skills of Summative Test Items in Physics of Grade X in Surakarta. Jurnal Pendidikan IPA Indonesia, 7(1), 3440.

Semwal, K., \& Bhatt, S. C. (2013). Study of Nd3+ ion as a Dopant in YAG and Glass Laser. International Journal of Physics, 1(1), 15-21.

Sinaga, P., \& Feranie, S. (2017). Enhancing Critical Thinking Skills and Writing Skills through the Variation in Non-Traditional Writing Task. International Journal of Instruction, 10(2), 69-84.

Stapleton, P., \& Amy, Y. (2015). Journal of English for Academic Purposes Assessing the Quality of Arguments in Students ' Persuasive Writing : A Case Study Analyzing the relationship Between Surface Structure and Substance. Journal of English for Academic Purposes, 17, 12-23.

Sugiyono, P. (2015). Metode penelitian kombinasi (mixed methods). Bandung: Alfabeta.

Sunarti, T., \& Prahani, B. K. (2018, March). The Effectiveness of CPI Model to Improve Positive Attitude Toward Science (PATS) for Pre-Service Physics Teacher. In Journal of Physics: Conference Series (Vol. 997, No. 1, p. 012013). IOP Publishing.

Susongko, P. (2016). Validation of Science Achievement Test with the Rasch Model. 
Jurnal Pendidikan IPA Indonesia, 5(2), 268277.

Tiruneh, D. T., Weldeslassie, A. G., Kassa, A., Tefera, Z., De Cock, M., \& Elen, J. (2016). Systematic Design of a Learning Environment for Domain Specific and DomainGeneral Critical Thinking Skills. Educational Technology Research and Development, 64(3), 481-505.

Torre, D., Manca, A., Durning, S., Janczukowicz, J., Taylor, D., \& Cleland, J. (2017). Learning at Large Conferences: From the 'Sage on the Stage' to Contemporary Models of Learning. Perspectives on medical education, 6(3), 205-208.

Vlachos, F., Avramidis, E., Dedousis, G., Chalmpe, M., Ntalla, I., \& Giannakopoulou, M. (2013). Prevalence and Gender Ratio of Dyslexia in Greek Adolescents and Its Association with Parental History and Brain Injury. American journal of educational research, $1(1), 22-25$.

Wijayanti, M. D., Raharjo, S. B., Saputro, S., \& Mulyani, S. (2018, May). Investigation to
Reduce Students' Misconception in Energy Material. In Journal of Physics: Conference Series (Vol. 1013, No. 1, p. 012080). IOP Publishing.

Wijayanti, M. D., Raharjo, S. B., Saputro, S., \& Mulyani, S. (2016). Identifying the Student's Critical Thinking Ability of PGSD in Accomplishing the Energy Material Problems. In Proceeding of the International Conference on Teacher Training and Education (Vol. 2, No. 1, pp. 695-701). Surakarta, Indonesia.

Yusrizal, Y. (2016). Analysis of Difficulty Level of Physics National Examination's Questions. Jurnal Pendidikan IPA Indonesia, 5(1), 140-149.

Zarifsanaiey, N., Amini, M., \& Saadat, F. (2016). A Comparison of Educational Strategies for the Acquisition of Nursing Student's Performance and Critical Thinking: SimulationBased Training vs. Integrated Training (Simulation and Critical Thinking Strategies). BMC Medical Education, 16(1), 294. 